\title{
USTAWODAWSTWO UNII EUROPEJSKIEJ WOBEC MNIEJSZOŚCI NARODOWYCH I ETNICZNYCH - CASUS ROMSKI
}

\author{
THE LEGISLATION OF THE EUROPEAN UNION \\ TOWARDS NATIONAL AND ETHNIC MINORITIES \\ - THE CASE OF ROMA
}

\begin{abstract}
The European Union is still in the stage of creating the system of protection of national and ethnic minorities. Attempts of the European Parliament to improve the situation in the European Union need research and reflection.

Social integration is the most important plane guaranteeing European integration, which is the basis for the future functioning of the European Union. The European community, which will be characterized by a common identity, will not be made up of individual countries but nations retaining their own diversity.

Despite many efforts of the European Union the situation of the Roma minority has not dramatically improved. The main reasons are insufficient actions by the European Union, corruption of officials, and lack of interest for the Roma community among the Member States. So far, the measures taken have not produced desired results, so it's necessary to devote more attention to this issue. The European Union needs strong support from other EU institutions and civil society. The main problem that affects the Roma community is long and difficult road to integration and acceptance by the other citizens of the European Union. A common phenomenon is the reluctance to strangers who are victims of discrimination. Strongly rooted stereotypes, lack of tolerance for other cultures proves that even the best-designed programs, as well as initiatives from the European Union are not sufficient. First of all, there
\end{abstract}

This is an Open Access article distributed under the terms of the Creative Commons Attribution 3.0 PL License (creativecommons.org/licenses/by/3.0/pl/), which permits redistribution, commercial and non-commercial, provided that the article is properly cited. (C) The Author(s) 2014.

Publisher: Institute of Slavic Studies PAS [Wydawca: Instytut Slawistyki PAN] 
is a need for commitment and unforced intercultural education from both the Roma and the rest of society, which will lead to mutual respect for differences.

The phenomenon of social exclusion of the Roma minority is often related to their lifestyle, habits and patterns different from the rest of the society. Help which is offered by the European Union and the Member States is generally perceived as an attempt to breach the culture of the Roma minority and replace it with another. That is why the European Union should develop a range of mechanisms and measures that may be accepted by the Roma.

Key words: European Union; law; national minorities; Roma

\section{STRESZCZENIE}

Unia Europejska znajduje się dopiero na etapie tworzenia systemu ochrony mniejszości narodowych i etnicznych, jednak niezbędne będzie podjęcie wielu starań, debat oraz działań, w które koniecznie zaangażowane muszą być wszystkie państwa członkowskie. Próby podejmowane przez Parlament Europejski w celu poprawy sytuacji mniejszości narodowych i etnicznych w Unii Europejskiej mogą być odpowiednim impulsem do wstępnych refleksji. Pomimo wielu starań Unii Europejskiej oraz wykorzystania funduszy unijnych sytuacja mniejszości romskiej nie uległa dużej poprawie. Głównymi przyczynami są niedostateczne działania ze strony Unii Europejskiej, korupcja urzędników, a także brak zainteresowania społecznością romską państw członkowskich. Dotychczas podjęte działania nie przyniosły zamierzonych rezultatów, dlatego konieczne jest poświęcenie większej uwagi tej kwestii. Unia Europejska potrzebuje mocnego wsparcia innych instytucji unijnych oraz społeczeństwa obywatelskiego.

Słowa kluczowe: ustawodawstwo Unii Europejskiej; mniejszości narodowe i etniczne; casus romski

Z różnicowany, ale głęboko zjednoczony kontynent europejski, zamieszkiwany przez mozaikę narodów, ludzi odmiennych kulturowo, etnicznie, językowo bądź religijnie, od podstaw tworzy odnowioną tożsamość oraz wspólną przyszłość (Łuczak, b.d.).

Ochrona prawna osób należących do mniejszości narodowych i etnicznych w ramach Unii Europejskiej jest współcześnie bardzo skomplikowanym zagadnieniem, dlatego wymagała w ostatnich latach od państw członkowskich poświęcenia znacznego zainteresowania. Widoczne jest wzmożenie aktywności kulturowej, co powoduje coraz częściej zauważalne przejawy świadomości odrębności, dlatego niezbędna jest reakcja ze strony państw członkowskich Unii Europejskiej oraz poszczególnych instytucji europejskich. Występowanie mniejszości narodowych i etnicznych jest naturalnym zjawiskiem w każdym państwie, a więc niezbędne jest dostosowanie prawodawstwa do panujących warunków w taki sposób, aby osoby należące do mniejszości narodowych i etnicznych były traktowane na równi z pozostałymi obywatelami (Chodubski, 2013, s. 33).

Celem niniejszego opracowania jest przedstawienie problemów, które dotykają mniejszości narodowe i etniczne w Unii Europejskiej, ukazanie konkretnych działań podejmowanych w ramach jej struktur oraz w poszczególnych państwach członkowskich na rzecz mniejszości narodowych i etnicznych. Szczególną uwagę zwrócono na sytuację oraz problemy, z którymi borykają się członkowie mniejszości romskiej. Romowie są najliczniej wy- 
stępującą grupą mniejszościową w Unii Europejskiej, a w ostatnich latach można zaobserwować coraz większe zainteresowanie Unii Europejskiej oraz państw członkowskich tą społecznością.

Tezą niniejszej pracy jest twierdzenie, że pomimo podejmowanych przez Unię Europejską oraz jej państwa członkowskie działań wobec mniejszości narodowych i etnicznych nadal występują ogromne dysproporcje w zagwarantowaniu im podstawowych praw i wolności. Mniejszości narodowe i etniczne nadal traktowane są w wielu państwach jako niechciane, w konsekwencji powszechnie widoczne jest zjawisko dyskryminacji.

W celu rozpatrzenia problemu postawiono następujące pytania badawcze:

1. Jak rozwijał się proces kształtowania prawodawstwa europejskiego w odniesieniu do mniejszości narodowych i etnicznych?

2. Jaki jest wkład i znaczenie instytucji Unii Europejskiej dla ochrony praw mniejszości narodowych i etnicznych?

3. Jak Traktat z Lizbony wpłynął na system ochrony praw mniejszości narodowych i etnicznych?

4. Jakie są główne priorytety oraz wyzwania Unii Europejskiej wobec mniejszości narodowych i etnicznych?

5. Jaką rolę i wpływ na politykę wobec mniejszości narodowych i etnicznych miała polska prezydencja w Unii Europejskiej?

6. Jakie działania podejmuje Unia Europejska na rzecz przeciwdziałania dyskryminacji wobec mniejszości?

7. Jakie inicjatywy podejmuje Unia Europejska w stosunku do mniejszości romskiej?

8. Z jakimi problemami zmaga się mniejszość romska w Unii Europejskiej?

Dla opracowania tematu posłużono się metodą analizy instytucjonalno-prawnej, z której skorzystano podczas interpretacji wykorzystanych aktów prawnych. W celu ukazania procesu kształtowania się prawodawstwa europejskiego w kwestii mniejszości narodowych i etnicznych oraz sytuacji społeczności romskiej posłużono się metodą historyczną.

\section{MNIEJSZOŚCI NARODOWE I ETNICZNE W PRAWODAWSTWIE MIĘDZYNARODOWYM}

\section{Proces kształtowania się prawodawstwa europejskiego w odniesieniu do mniejszości narodowych i etnicznych}

Pomimo wielu badań nie udało się do czasów współczesnych wypracować jednoznacznej definicji mniejszości narodowej. Wynika to z faktu, że „narodowość jest stanem świadomości każdego człowieka i wynikającą z tego stanu jego identyfikacją z daną grupą etniczną" (Janusz \& Bajda, 2000, s. 11). Pojęciem mniejszość narodowa posłużono się dopiero w XIX wieku. Wcześniej termin ten nie posiadał w prawie międzynarodowym jednej i powszechnie obowiązującej definicji. Nawet współcześnie wywołuje kontrowersje i nieporozumienia, które wynikają w dużej mierze z różnych interesów poznawczych. Wielokrotnie podejmowano próby sformułowania prawnej definicji, zwłaszcza podczas prac nad dokumentami, które odnosiły się do ochrony praw mniejszości (Malicka, 2004, s. 11). Termin mniejszość wywodzi się z łacińskiego określenia minor i oznacza mniejszy. Jedną z ważniejszych definicji opracowała Rada Europy na potrzeby Komisji Weneckiej, określając mniejszość narodową jako grupę liczebnie mniejszą od pozostałej części popu- 
lacji państwa, której członkowie jako obywatele danego państwa dysponują etnicznymi, religijnymi lub językowymi cechami, które są odmienne od cech pozostałych mieszkańców oraz wyrażają wolę zachowania własnej kultury, tradycji, religii lub języka (Gronowska, 1991, s. 119).

Brak jednoznacznej definicji mniejszości narodowej nie wpływa w żaden sposób na proces kształtowania się i rozszerzania ochrony praw mniejszości. W aktach prawnych, w których poruszano powyższą kwestię, tolerowana jest taka sytuacja, w innym wypadku niemożliwe byłoby ich zatwierdzenie oraz przyjęcie. Bez wątpienia można stwierdzić, iż istnienie mniejszości narodowych jest faktem, a nie problemem prawa. Władze poszczególnych państw mają swoistą swobodę w uznawaniu określonej populacji jako mniejszości narodowej.

Państwa w Europie można podzielić na dwie grupy, biorąc pod uwagę kryterium definiowania pojęcia mniejszości narodowej oraz akceptację koncepcji ochrony mniejszości. Pierwszą grupę stanowią państwa, którym obce jest określenie mniejszość narodowa. Istnieje równowaga pomiędzy terminem narodowość a obywatelstwo, a przeciwieństwem dla dwóch poprzednich jest określenie cudzoziemiec. W skład drugiej grupy wchodzą państwa, które doskonale znają definicję mniejszości narodowej i stosują się do niej. W większości przypadków istnieje to na skutek sprecyzowania w określonych dokumentach oraz aktach prawnych konkretnych grup (Łodziński, 2006, ss. 205-206).

Do rozwoju ochrony praw mniejszości narodowych i etnicznych przyczyniła się działalność wielu organizacji międzynarodowych. Jedną z takich organizacji jest Unia Europejska. Państwa członkowskie Unii Europejskiej we własnym zakresie starają się rozwiązywać kwestie mniejszości narodowych w oparciu o wewnętrzne prawodawstwo. Wyjątek stanowi problem bezpieczeństwa granic zewnętrznych Unii, ich zabezpieczenia przed niemile widzianymi imigrantami, a także kwestie uchodźstwa politycznego (Łukaszuk, 1990, s. 12). W porównaniu do Rady Europy, Organizacji Narodów Zjednoczonych czy współczesnej Organizacji Bezpieczeństwa i Współpracy w Europie nia Europejska sporadycznie odnosiła się do kwestii ochrony mniejszości narodowych i etnicznych. Jedną z ważniejszych przyczyn takiej sytuacji był fakt, iż integracja europejska przede wszystkim skierowana była na sprawy gospodarcze oraz instytucjonalne. Unia Europejska nie jest klasyczną organizacją międzynarodową. Jest organizacją ponadnarodową ustanawiającą jednolite prawo charakteryzujące się nadrzędnością oraz bezpośredniością wobec prawa krajowego. Błędne byłoby jednak stwierdzenie, że Unia Europejska nie odnosiła się w żaden sposób do poruszanego problemu. Jednym z przykładów takich działań była ochrona mniejszości językowych lub języków mniejszościowych w państwach członkowskich, która miała miejsce w latach 80. XX wieku (Łobodziński, 2002, s. 26).

Widoczne zmiany $w$ sposobie postrzegania praw mniejszości i ich ochrony nastąpiły $w$ latach 90. Spowodowane to było przede wszystkim wymogami związanymi z procesem rozszerzania się Unii Europejskiej oraz coraz silniej podkreślanymi ambicjami reprezentowania wartości demokratycznych. Skutkiem tej sytuacji było przyjęcie tzw. kryteriów kopenhaskich podczas posiedzenia Rady Europejskiej w 1993 roku w Kopenhadze (Tulipan, 2002, ss. 15-16). Spełnienie tych kryteriów dawało państwom możliwość ubiegania się o status członka Unii Europejskiej. Obok demokracji, rządów prawa oraz praw człowieka politycznym warunkiem kopenhaskim jest także respektowanie i ochrona praw mniejszości narodowych. Państwa kandydujące zobowiązują się do zagwarantowania przestrzegania praw mniejszości narodowych i etnicznych na własnych terytoriach. Kryteria mają przede wszystkim charakter polityczny, nie mają natury prawnej, a więc nie są 
zobowiązujące w tym względzie. Podczas egzekwowania przestrzegania kryteriów kopenhaskich zjawiskiem pobocznym stały się „podwójne standardy”, które polegały na nakładaniu obowiązku ochrony praw mniejszości narodowych i etnicznych jedynie na państwa kandydujące (Pawlikowski, 2011, s. 285).

Współcześnie prym w kwestii wypracowania zasad ochrony mniejszości narodowych w Europie wiedzie Rada Europy. Członkami organizacji międzynarodowej jest większość państw należących do Unii Europejskiej, dlatego należy podkreślić rolę Unii w procesie kształtowania systemu ochrony praw mniejszości narodowych i etnicznych (Łobodziński, 2002, s. 200). Pierwszym europejskim aktem prawnym, który odnosit się do problemu ochrony praw mniejszości narodowych była Konwencja Ramowa Rady Europy o Ochronie Mniejszości Narodowych (Framework Convention for the Protection of National Minorities) z 1 lutego 1995 roku („,Konwencja Ramowa o Ochronie Mniejszości Narodowych z dnia 1 lutego 1995 roku", 2002). Zawarto w niej zapis, że ochrona mniejszości narodowych stanowi integralną część międzynarodowego systemu ochrony praw człowieka. Dokument był swoistą gwarancją równości wobec prawa oraz ochrony prawnej osób należących do mniejszości narodowych. Każde państwo poprzez podpisanie tej konwencji zobowiązało się do zapewnienia właściwej ochrony w dziedzinie życia politycznego, kulturalnego, ekonomicznego oraz społecznego. W dokumencie tym kreowano podstawowe standardy polityczne i prawne ochrony praw mniejszości narodowych w Europie (Pawlak, 2001, s. 14).

\section{Rola i znaczenie Unii Europejskiej dla ochrony praw mniejszości narodowych i etnicznych}

Zasadniczą rolę w dziedzinie podnoszenia kwestii ochrony mniejszości w Unii Europejskiej odgrywają jej trzy instytucje: Parlament Europejski, Komisja Europejska oraz Rada Europejska. Działalność wymienionych organów w odniesieniu do ochrony mniejszości narodowych i etnicznych, a także walki z dyskryminacją etniczną i rasową przejawia się w poniższych grupach działań. Pierwszą z nich stanowią polityczno-normatywne starania Parlamentu Europejskiego, kolejna to aktywność Komisji Europejskiej, Rady Europejskiej oraz Parlamentu Europejskiego, które mają charakter celowy oraz finansowy. Innymi działaniami są te podejmowane przez instytucje Unii Europejskiej w ramach relacji międzynarodowych dotyczących szczególnie kwestii mniejszości i spraw mniejszościowych poza obszarem jej wpływów (Łobodziński, 2002, s. 27). Instytucją, która pierwsza wykazała zainteresowanie statusem mniejszości narodowych i etnicznych we Wspólnotach Europejskich, był Parlament Europejski. Działania związane z powyższą kwestią po raz pierwszy podjęto w latach 80 . XX wieku.

W latach 1979-1984 Komisja Prawna Parlamentu Europejskiego prowadziła prace przygotowawcze nad sporządzeniem dokumentu, który miał normować pozycje mniejszości. Parlament Europejski wielokrotnie w ciągu kolejnych kadencji wzywał państwa członkowskie Unii Europejskiej do poszanowania praw mniejszości, przede wszystkim tych odnoszących się do edukacji, mediów oraz posługiwania się językiem mniejszościowym w kontaktach urzędowych (Janiszewski, 2013b, ss. 39-47). Instytucja ta wydała szereg rezolucji, które odnosiły się do problematyki sytuacji oraz ochrony mniejszości narodowych. Niestety w niewielu przypadkach przyniosły one praktyczne efekty, ponieważ nie mają charakteru prawnie obowiązującego.

Kolejną instytucją Unii Europejskiej, która odnosi się do problematyki mniejszości narodowych i etnicznych jest Komisja Europejska. Działania Komisji w kwestii mniejszości 
mają charakter wyłącznie finansowy lub techniczny podejmowane są samodzielnie lub we współpracy z innymi organami Unii Europejskiej. Ważną organizacją pozarządową dla osób należących do mniejszości jest Europejskie Biuro Języków Mniejszościowych (European Bureau of Minority Languages) powołane do istnienia w 1982 roku. Zadaniem biura jest wspieranie w kwestiach prawnych, politycznych oraz finansowych społeczności posługujących się językami mniejszościowymi. Komisja Europejska ma własny udział w działalności Biura, ponieważ z jej środków jest ono głównie finansowane. Instytucja ta była także odpowiedzialna za finansowanie studiów nad mniejszościami językowymi w wielu państwach członkowskich Unii Europejskiej. Jest ona także realizatorem Otwartej Metody Koordynacji, która polega na uzgodnieniu określonej strategii działania odnoszącej się do wybranej dziedziny realizowanej przez państwa członkowskie Unii Europejskiej. W każdym roku wybierana jest inna tematyka, wokół której skupiają się czynności informacyjne wszystkich członków Unii Europejskiej. Powyższe działania mają skoncentrować uwagę społeczeństwa na znaczących sprawach, uaktywnić jego wrażliwość oraz zainicjować debaty społeczne, a w ostateczności doprowadzić do oczekiwanych zmian (Łobodziński, 2002, ss. 30-31).

Komisja Europejska jest odpowiedzialna za przygotowywanie Raportów Okresowych w państwach, które są kandydatami do członkowstwa w Unii Europejskiej. Raporty przedstawiają reformy i działania państw kandydujących związane z wypełnianiem kryteriów kopenhaskich, które są warunkiem koniecznym do osiągnięcia statusu członka Unii Europejskiej. Następnie raporty państw kandydujących są analizowane oraz scalane w całość. W raporcie za 2001 rok znalazł się oddzielny podrozdział poświęcony osobom należącym do mniejszości narodowych, w którym popierano działania o charakterze międzynarodowym na rzecz ochrony praw mniejszości („European Union Annual Report on Human Rights 2001", b.d., ss. 101-102). Ochrona praw mniejszości narodowych jest bardzo istotną kwestią we współczesnych czasach. Każdemu państwu powinno zależeć, aby każdy obywatel czuł się w nim swobodnie i mógł korzystać z pełni praw, które zagwarantowane są w prawie wewnętrznym.

Ostatnim organem Unii Europejskiej wpływającym na kształtowanie ochrony praw osób należącym do mniejszości narodowych i etnicznych jest Rada Europejska. Instytucji tej zawdzięcza się przyjęcie kryteriów kopenhaskich w 1993 roku. Rada Europejska po spotkaniu w Kopenhadze stwierdziła, iż niezbędnym warunkiem, który muszą spełnić państwa kandydujące do Unii Europejskiej, jest posiadanie stabilnych instytucji wewnętrznych stojących na straży najważniejszych praw i wolności, szczególnie demokracji, rządów prawa, ale także zapewnienie poszanowania praw człowieka i ochrona mniejszości. Kolejnym działaniem Rady Europejskiej zmierzającym do aktywniejszej polityki wobec ochrony praw mniejszości narodowych i etnicznych było przyjęcie Paktu o Stabilizacji (Stability Pact). Pakt miał być pewnego rodzaju zabezpieczeniem przed ewentualnymi konfliktami pomiędzy państwami Europy Środkowej i Wschodniej. W obawie przed dalszymi losami Europy postanowiono potwierdzić w powyższym dokumencie nienaruszalność granic oraz zagwarantować ochronę mniejszości narodowych. Pakt o Stabilizacji przyczynił się do złagodzenia sytuacji w Europie, wykorzystując zabieg łagodzenia konfliktów i sporów za pomocą zawieranych traktatów dwustronnych. Szczególnym dokumentem poświęconym analizowanej kwestii jest Dyrektywa Rady 2000/43/WE z dnia 29 czerwca 2000 roku wprowadzająca w życie zasadę równego traktowania osób bez względu na pochodzenie rasowe lub etniczne ("Dyrektywa Rady 2000/43/WE”, 2000, ss. 22-26). 
13 grudnia 2007 roku w Lizbonie podpisano Traktat lizboński, który zmieniał dwa najważniejsze traktaty Unii Europejskiej, Traktat o Unii Europejskiej (Treaty on European Union) i Traktat ustanawiający Wspólnotę Europejską (Traktat o funkcjonowaniu Unii Europejskiej). Traktat z Lizbony miał znaczący wpływ na dalszą perspektywę rozwoju praw oraz ochrony mniejszości narodowych i etnicznych w Unii Europejskiej. Wprowadził istotne zmiany w pierwotnym prawie unijnym. Najważniejszym „osiągnięciem” analizowanego Traktatu było umieszczenie w Traktacie o Unii Europejskiej pojęcia mniejszości (Janiszewski, 2013b, s. 51).

Kolejnym pozytywnym działaniem odnoszącym się do problematyki mniejszości narodowych i etnicznych było uprawomocnienie, wejście w życie oraz włączenie do prawa pierwotnego Karty Praw Podstawowych Unii Europejskiej (Charter of Fundamental Rights of the European Union) ("Karta Praw Podstawowych Unii Europejskiej”, 2012, s. 2). W dokumencie poruszono kwestię zakazu jakichkolwiek przejawów dyskryminacji ze względu na płeć, rasę, religię bądź wyznanie, a co na najważniejsze stał się on aktem prawnie wiążącym, co oznacza, że ma analogiczną range jak traktaty (European Union Agency for Fundamental Rights, 2011, s. 22).

Powyższe kładły większy nacisk na respektowanie praw mniejszości narodowych i etnicznych w odniesieniu do zadań oraz obowiązków organów, instytucji, a także jednostek Unii Europejskiej. Należy zaznaczyć, iż wraz z wejściem w życie dnia 1 grudnia 2009 roku Traktatu lizbońskiego Unia Europejska przystąpiła do Konwencji o Ochronie Praw Człowieka i Podstawowych Wolności (Convention for the Protection of Human Rights and Fundamental Freedoms) (Pawlikowski, 2011, s. 286). Traktat z Lizbony oraz Karta Praw Podstawowych, która stanowi jego nieodłączny element, jest wyraźnym sygnałem, że Unia Europejska poświęcała więcej uwagi działaniom w tej kwestii. W ostatnich latach prawa człowieka, swobody obywatelskie czy ochrona praw mniejszości narodowych i etnicznych w Unii Europejskiej należały do problemów zaniedbywanych przez instytucje oraz prawodawstwo unijne (Koss-Goryszewska, 2010, s. 5). Postanowienia Traktatu lizbońskiego spowodowały wzrost aktywności Unii Europejskiej w dziedzinie ochrony osób należących do mniejszości narodowych i etnicznych, a kwestie te znalazły się na szczycie unijnej hierarchii wartości, czyli w obrębie prawa pierwotnego.

\section{PRIORYTETY I WYZWANIA UNII EUROPEJSKIEJ WOBEC MNIEJSZOŚCI NARODOWYCH I ETNICZNYCH}

\section{Polityka edukacyjna Unii Europejskiej wobec mniejszości narodowych i etnicznych}

Unia Europejska jako jedna z wielu instytucji podejmujących działania w kwestii edukacji, kładzie szczególny nacisk na sprawy szkolnictwa, czyniąc edukacje jednym z najważniejszych filarów rozwoju Wspólnoty Europejskiej. Polityka edukacyjna stanowi jeden z wielu priorytetów Unii Europejskiej. Każde państwo członkowskie samodzielnie rozwija system edukacyjny, ale jednocześnie zmierza do stworzenia oraz ujednolicenia wspólnej dla całej Unii Europejskiej polityki edukacyjnej. Za wyznaczanie priorytetów wspólnego działania państw członkowskich odpowiedzialni są ministrowie edukacji (Kowalewski, 2006, s. 519). 
Unia Europejska nie wyznacza standardów edukacyjnych skierowanych do mniejszości narodowych i etnicznych, które byłyby ogólnie obowiązujące. Pomocne w tej kwestii są międzynarodowe i regionalne narzędzia prawa, które tworzą i wyznaczają normy odnoszące się do ochrony mniejszości narodowych i etnicznych, a także ustalają wzorce, do których państwa członkowskie powinny dążyć w celu osiągnięcia harmonii. Wybrane wewnętrzne regulacje problemów edukacyjnych mniejszości narodowych i etnicznych w poszczególnych państwach członkowskich można traktować jako przykład rozwiązań, które byłyby najlepsze w tej kwestii. Dokumenty o charakterze uniwersalnym i regionalnym, które mogą okazać się przydatne w tworzeniu unijnych standardów edukacyjnych, to między innymi Konwencja w sprawie Zwalczania Dyskryminacji w Dziedzinie Oświaty (Convention against Discrimination In Education) z 15 listopada 1960 roku („Konwencja w sprawie Zwalczania Dyskryminacji w Dziedzinie Oświaty", b.d.). W dokumencie zapewniono osobom należącym do mniejszości narodowych i etnicznych prowadzenie działalności oświatowej w połączeniu z zarządzaniem placówkami szkolnymi. Konwencja Ramowa o Ochronie Mniejszości Narodowych i Etnicznych ( Framework Convention for the Protection of National Minorities) z 1 lutego 1995 roku zawiera zapis, iż wszystkie państwa, które są stronami konwencji, wyrażają zgodę na kierowanie własnymi, prywatnymi placówkami oświatowymi przez mniejszości narodowe i etniczne. Najważniejszym dokumentem, w którym poruszono kwestie ochrony języków mniejszości, jest Europejska Karta Języków Regionalnych i Mniejszościowych (European Charter for Regional for Minority Languages) 5 listopada 1992 roku („Europejska Karta Języków Regionalnych ¡ Mniejszościowych", 2000, s. 173). W karcie zawarto szereg standardów, które odnoszą się do polityki edukacyjnej mniejszości.

Począwszy od lat 80. XX wieku coraz więcej uwagi państwa członkowskie Unii Europejskiej poświęcają praktykom edukacyjnym, które należy popierać oraz propagować w każdym państwie. Wielokulturowość w państwach członkowskich Unii Europejskich stanowi istotne wyzwanie dla systemów edukacyjnych. Współcześnie wśród osób należących do mniejszości narodowych i etnicznych uwidacznia się silna potrzeba nauki rodzimych języków i kultur państwa pochodzenia. Ostatecznym celem Unii Europejskiej jest edukacja międzykulturowa (Rusnarczyk, b.d., s. 2). Polityka edukacyjna Unii Europejskiej akcentuje problem dostępu do edukacji jako kluczową kwestię integracji mniejszości narodowych i etnicznych z obywatelami danego państwa członkowskiego. Unia Europejska, stosując wiele działań i zabiegów w kwestii edukacyjnej, dąży do tworzenia europejskiej tożsamości, poczucia harmonii i integralności obywateli zjednoczonej Europy. Występowanie wielu grup kulturowych w Unii Europejskiej oraz w poszczególnych państwach członkowskich jest pozytywnym zjawiskiem, które stwarza możliwość kreowania instytucjonalnych warunków wspótistnienia. Unia Europejska zapewnia państwom członkowskim swobodę w kwestii wyboru metod oraz sposobów wdrażania polityki edukacyjnej wobec mniejszości narodowych i etnicznych, a tym samym koncepcje w państwach członkowskich Unii Europejskiej nie są spójne (Szelewa, 2010, ss. 7-9).

Polityka edukacyjna Unii Europejskiej musi zostać przystosowana do potrzeb społeczeństwa oraz gospodarki, która oparta jest na wiedzy. Korzystnym zabiegiem, który poprawiłby poziom edukacji w państwach członkowskich, byłoby dostosowanie szkolnictwa do różnych grup kulturowych. Współdziałanie państw członkowskich Unii Europejskiej przyniosto osiągnięcie zamierzonego efektu w reformach systemów edukacji w wielu państwach, prowadząc do przystosowania procesu kształcenia do szybko zmieniającego się w wymiarze europejskim i międzynarodowym otoczenia (Kowalewski, 2006, s. 537). 
Dyskryminacja definiowana jest jako całokształt postępowań, które prowadzą do bezpodstawnego różnicowania ludzi ze względu na posiadanie odmiennych cech, w szczególności pochodzenia, rasy, języka czy wieku, skutkiem powyższego jest ograniczenie uznania, wykonywania lub posługiwania się w równy sposób z pozostałymi obywatelami prawami człowieka i podstawowymi wolnościami w głównych dziedzinach życia społecznego (Machocka, 2006, ss. 101-106). Kwestia przeciwdziałania dyskryminacji wobec mniejszości narodowych i etnicznych odgrywa ważną rolę w procesie integracji europejskiej. Przejawia się w sposobie „reagowania na problemy mniejszości, które stoją wobec ryzyka zarówno wykluczenia, jak i asymilacji. Właściwie należy myśleć o tych formach, jak o aspektach jednego całościowego podejścia" (Tulipan, 2002, s. 12).

Proces dyskryminacji związany jest z brakiem tolerancji, uprzedzeniami oraz negatywnymi stereotypami (Divido, Brigham, Johnson, \& Gaertner, 1999, ss. 236-237). Ze względu na formę przejawów dyskryminacji wyróżnia się dyskryminację bezpośrednią i pośrednią. Dyskryminacja bezpośrednia charakteryzuje się nieuzasadnionym negatywnym traktowaniem osób posiadających odmienne cechy w porównaniu z innymi obywatelami danego państwa, którzy znajdują się w podobnej sytuacji. Pod określeniem dyskryminacji pośredniej rozumiane jest podejmowanie rozwiązań prawnych, działań instytucji publicznych oraz warunki życia, które pozbawiają osoby należące do mniejszości narodowych i etnicznych równouprawnienia względem pozostałych obywateli danego państwa (Grzymała-Kozłowska, 2002, ss. 188-190).

Unia Europejska prowadzi wiele działań, które mają na celu walkę ze zjawiskiem dyskryminacji. W ramach instytucji unijnych realizowana jest między innymi strategia na rzecz wielojęzyczności, która jest mało rozpowszechniona w świadomości obywateli Unii Europejskiej. Faktem jest, że mieszkańcy Unii Europejskiej posługują się odmiennymi językami, które w państwach członkowskich podzielić można na oficjalne, używane potocznie, oraz rdzenne języki poszczególnych narodowości. Nie ulega wątpliwości, że nauka języków obcych jest koniecznością, tak, by w przyszłości skutkuje wszyscy obywatele Unii Europejskiej władali językiem ojczystym oraz dwoma obcymi. Komisja Europejska jest odpowiedzialna za prowadzenie kampanii promującej wielojęzyczność, która ma na celu nie tylko rozwijanie umiejętności posługiwania się kilkoma językami, ale także promowanie wspótistnienia wielu odmiennych społeczności językowych na jednym obszarze geograficznym. Unia Europejska często zaznacza, że wielojęzyczność jest główną wartością europejską, przyczynia się do występowania bogactwa kultur i społeczności na jednym obszarze (Zygierewicz, 2011, ss. 92-93).

Instytucją Unii Europejskiej, która poświęca najwięcej uwagi kwestiom związanym z przeciwdziałaniem dyskryminacji wobec mniejszości narodowych i etnicznych, jest Komisja Europejska. Podkreśla się, że wygranie walki z dyskryminacją możliwe jest jedynie poprzez podejmowanie przez państwa członkowskie wielu działań, przede wszystkim realizowanie programów oraz kampanii informacyjnych. Działaniem tego typu była zapoczątkowana przez Unię Europejską w czerwcu 2003 roku kampania informacyjna "Za różnorodnością. Przeciw dyskryminacji". Celem przedsięwzięcia było nie tylko uświadomienie obywatelom Unii Europejskiej, jakie posiadają prawa, czym jest dyskryminacja oraz jak przeciwstawiać się temu zjawisku, ale także podkreślenie korzyści, które niesie za sobą różnorodność kulturowa. W kampanię zaangażowane są wszystkie podmioty, które wykazują zainteresowanie problemem nietolerancji osób należących do mniejszości narodowych i etnicznych, skupia ona ponad 500 organizacji. W ramach działań informacyjnych 
organizowane są różnego rodzaju imprezy, konferencje oraz seminaria. Do najważniejszych zaliczyć można „Szczyt Równości” czy „Dni Różnorodności” (Machocka, 2006, ss. 108-109). Kolejnym programem Unii Europejskiej, który ma na celu przeciwdziałanie dyskryminacji jest PROGRESS. Projekt polega na udzielaniu wsparcia finansowego różnego rodzaju instytucjom, które realizują działania Unii Europejskiej w kwestii między innymi walki z dyskryminacją („PROGRESS programme (2007-2013)”, b.d.).

W raporcie o dyskryminacji w Unii Europejskiej z 2009 roku (Discrimination in the EU in 2009) ("Discrimination in the EU”, 2009) przygotowanym dla Komisji Europejskiej wskazano, iż najbardziej rozpowszechnionym zjawiskiem w Unii jest dyskryminacja etniczna. Dane opracowane $\mathrm{w}$ raporcie wskazują, iż pomimo istnienia rozbudowanych aktów prawnych większość społeczeństwa państw członkowskich Unii Europejskiej zauważa zjawisko dyskryminacji (Wencel, 2009, s. 2).

\section{Prezydencja Polski w Unii Europejskiej i jej wpływ na polityke wobec mniejszości narodowych i etnicznych}

Polska sprawowała półroczną prezydencję w Radzie Unii Europejskiej w okresie od 1 lipca do 31 grudnia 2011 roku, a wspólny osiemnastomiesięczny program przygotowała we współpracy z Danią i Cyprem. Pełniona cyklicznie przez każde państwo członkowskie Unii Europejskiej prezydencja to czas trudnej odpowiedzialności za główne kierunki rozwoju państwa, a przede wszystkim prowadzenie negocjacji w gronie państw członkowskich. Przewodnictwo w instytucji Unii Europejskiej daje możliwości prestiżu i szansy na wieloaspektowe promowanie własnego kraju, zarówno w wymiarze politycznym, gospodarczym jak i kulturowym. Bez wątpienia czas ten obfitował w ważne wydarzenia i problemy wymagające szczególnej aktywności parlamentarzystów. Obok głównych priorytetów polskiej prezydencji w Radzie Unii Europejskiej, które w znacznej mierze zostały zrealizowane, należy wymienić sprawy wymagające mniejszej uwagi, ale równie znaczące dla Polski, które współcześnie stanowią ogromne wyzwanie (Przewodnictwo Polski w Radzie Unii Europejskiej: raport końcowy z przygotowania i sprawozdania prezydencji, 2012, ss. 8-9).

W ramach polskiej prezydencji w Radzie Unii Europejskiej w dniach od 14 do 16 września 2011 roku odbyła się międzynarodowa konferencja naukowa na temat „Mniejszości narodowe, etniczne i językowe w Unii Europejskiej", która miała miejsce w Lublinie. Wybór miasta, w którym odbywało się sympozjum, nie było przypadkowe. Lublin jest miastem, które od wieków ma tradycje wielokulturowe. Przez stulecia miasto zamieszkiwali Żydzi, Ukraińcy, Czesi, Rosjanie i wiele innych narodowości, dla których wzajemne współistnienie nigdy nie stanowiło problemu. Ciekawostką jest także to, iż Lublin jako jedyne polskie miasto został wybrany do próbnego programu Rady Europy oraz Komisji Europejskiej „Miasta Międzykulturowe” („Mniejszości narodowe, etniczne i językowe w Unii Europejskiej", b.d.). Pieczę nad wydarzeniem towarzyszącemu polskiej prezydencji objęli ówczesny przewodniczący Parlamentu Europejskiego Jerzy Buzek i Marszałek Sejmu Rzeczypospolitej Polskiej Grzegorz Schetyna. Celem konferencji było przede wszystkim przeprowadzenie analizy aktualnej sytuacji mniejszości narodowych, etnicznych i językowych w państwach Unii Europejskiej, jak również wzajemna wymiana poglądów i doświadczeń wynikających z przeprowadzonych badań. Ponadto konferencja poświęcona była problemom dotyczącym zachowania tożsamości narodowej, pielęgnowania kultury i języka mniejszości (Sulimowicz, 2011, s. 18). 
Podczas spotkania uczestnicy poddali pod dyskusję wielopłaszczyznową problematykę mniejszości narodowych i etnicznych: od czynników historycznych poprzez sytuację prawną po wymiar kulturoznawczy i socjologiczny. Wydarzenie miało uroczysty charakter. W konferencji wzięli udział przedstawiciele mniejszości, naukowcy z ośrodków badawczych, reprezentanci instytucji europejskich, a także przedstawiciele państw członkowskich Unii Europejskiej („Wieści z Ratusza: Konferencja «Mniejszości narodowe, etniczne i językowe w Unii Europejskiej» dobiegła końca", 2011). Wśród najczęściej poruszanych aspektów wymieniano problemy mniejszości na przykładzie Polski dotyczące walki o równość społeczną, ekonomiczną, jak również o sprawiedliwość kulturową, której celem jest ochrona kultury, tradycji i języka mniejszości. Uczestnicy konferencji najczęściej wymieniali przede wszystkim konieczność tworzenia instytucji kultury poszczególnych mniejszości, a także potrzebę nagłaśniania tych problemów przez media publiczne („Problematyka mniejszości w UE na konferencji w Lublinie", 2011).

Konferencja zorganizowana w Lublinie okazała się ogromnym sukcesem, a to z uwagi na charakter jej tematyki. Kwestia mniejszości narodowych i etnicznych jest często pomijana, a nawet uznawana za niewymagającą publicznego poruszania. Wiąże się to z trudną akceptacją mniejszości narodowych i etnicznych reprezentujących odmienną kulture przez społeczeństwo, a w konsekwencji towarzyszącymi wciąż stereotypami. Wydarzenie ukazało zwiększone zainteresowanie społeczeństwa polskiego mniejszościami narodowymi i etnicznymi, jak też przyczyniło się do pozytywnej oceny Polski podczas sprawowanej prezydencji w Radzie Unii Europejskiej. Konferencja naukowa w Lubliniea wpłynęła pozytywnie na wizerunek Polski wśród państw członkowskich Unii Europejskiej. Poświęcenie sympozjum tematyce ochrony praw mniejszości narodowych i etnicznych w Unii Europejskiej uświadomiło jej uczestnikom, że jest to zagadnienie, którego nie można bagatelizować, z należy poświęcić jej więcej uwagi m.in. w prawodawstwie wewnętrznym państw członkowskich oraz ogólnym prawie unijnym. Konferencja doprowadziła do wypracowania wspólnej analizy sytuacji mniejszości narodowych, etnicznych i językowych w państwach członkowskich Unii Europejskiej.

\section{POLITYKA UNII EUROPEJSKIEJ WOBEC MNIEJSZOŚCI ROMSKIEJ}

\section{Spoteczność romska w Unii Europejskiej}

Romowie zamieszkujący państwa Europy są najliczniejszą mniejszość etniczną w Unii Europejskiej. Grupa mniejszości romskiej często określana jest jako "naród nieterytorialny", który nie wykazuje żadnych dążeń do utworzenia własnego państwa. Współcześnie społeczność Romów jest trudno jednoznacznie określić ze względu na fakt, iż mniejszość romska ukrywa tożsamość narodową, obawiając się wykluczenia społecznego przejawiającego się wrogością i uprzedzeniami silnie zakorzenionymi w świadomości ludzkiej. Największe skupiska Romów znajdują się w zachodniej części Europy; wybierają oni przede wszystkim Włochy, Francję i Hiszpanię (Socha, 2010, s. 1). Sytuacja społeczności romskiej jest problemem ogólnoeuropejskim, ponieważ Romowie są na liczniejszą mniejszością etniczną w Europie.

Komisja Europejska regularnie bada sytuację społeczną, ekonomiczną, a także kulturalną Romów, którzy przebywają w państwach europejskich. Z raportów Komisji wynika, iż społeczność romska w porównaniu z resztą obywateli wciąż znajduje się w cieniu biedy 
oraz niedostatku ekonomicznego, a także boryką się z ogromnymi trudnościami związanymi z integracją. Według badaczy odpowiedzialnych za przygotowanie raportów, winą należy obarczyć w szczególności państwa członkowskie Unii Europejskiej, które nie ponoszą i nie chcą ponosić odpowiedzialności za mniejszość romską, a w konsekwencji nie czują potrzebyi podejmowania konkretnych działań, które mogłyby przyczynić się do polepszenia sytuacji Romów (Szymańczak, 2012, ss. 1-2).

Społeczności romskie we wszystkich państwach są narażone na dyskryminację etniczną, wykluczenie społeczne, które przejawiają się głównie w wielu ograniczeniach życia społecznego (m.in. ograniczony wpływ na życie polityczne, segregacja szkolna). Główną przyczyną nietolerancji miejscowej społeczności jest przede wszystkim powszechna nieznajomość kultury mniejszości romskiej, posługiwanie się stereotypami, co stanowi częsty argument wymieniany w państwach europejskich (Szewczyk, 2007, s. 189). Jak wskazują badania przeprowadzone przez Agencję Praw Podstawowych Unii Europejskiej The European Union Agency for Fundamental Rights) jedynym problemem Romów nie jest ich dyskryminowanie, ale także niska świadomość posiadanych praw oraz pogłębiająca się niewiara, ostrożność i brak zaufania w stosunku do instytucji publicznych, które powinny w sposób szczególny stać na straży przestrzegania praw oraz swobód mniejszości romskiej (European Union Agency for Fundamental Rights, 2009, s. 12). Wyniki pokazują, że niezbędne są szybkie i skuteczne działania państw członkowskich Unii Europejskiej zmierzające ku poprawie poziomu edukacji, zatrudnienia wśród Romów.

Unia Europejska musi podjąć konkretne działania, które przyczynią się do zmiany sytuacji mniejszości romskiej. I tak, kwestia społeczno-bytowa Romów jest sprzeczna z fundamentalnymi zasadami i wartościami Unii Europejskiej (równością i niedyskryminacją, zawartymi w zapisach prawa Unii Europejskiej). W walce z dyskryminacją Unia Europejska zaleciła przyjęcie Dyrektywy wprowadzającej w życie zasadę równego traktowania bez względu na rasę oraz pochodzenie etniczne. Dyrektywą 2000/43/WE nakłada się na wszystkie państwa członkowskie Unii Europejskiej obowiązek zapewnienia wszystkim obywatelom bez względu na różnorodność cech zewnętrznych równego dostępu do edukacji, służby zdrowia, zatrudnienia, kształcenia zawodowego, ochrony socjalnej oraz korzystania ze świadczeń socjalnych. W wielu państwach europejskich społeczność romska określana jest jako nielegalni imigranci, najczęściej powodem takiego nazewnictwa jest brau dokumentów potwierdzających tożsamość czy świadectwa urodzenia. Ponadto znaczna część mniejszości romskiej zamieszkującej Unię Europejską niedma uregulowanego statusu prawnego, co też przyczynic się do powstenia bariery między społecznością romską a pozostałymi obywatelami (Krasnowski, 2011, s. 14).

Zjawisko marginalizacji mniejszości romskiej w dalszym ciągu jest powszechne oraz obecne niemal we wszystkich sferach: kulturowych, społecznych i ekonomicznych. Romowie od niedawna poczuli silną potrzebę organizowania się, walki o własną przyszłość. Stali się aktywną mniejszością, wyraźnie akcentującą swoje dążenia oraz prawa. Pomimo powszechnego wykluczenia mniejszość romska nie poddaje się, kształtuje swoją odmienność i walczy o „zauważenie” problemów, które wymagają szybkiej reakcji ze strony państw członkowskich Unii Europejskiej. Unia Europejska nie jest obojętna na trudności mniejszości romskiej; okazuje swe zainteresowanie, proponując różnego rodzaju programy pomocowe oraz aktywizueąc władze państwowe do podejmowania działań, które przyczynią się do poprawy losu Romów (Kwadrans, 2007, ss. 225-226). 
Unia Europejska oraz jej państwa członkowskie mają szczególne zobowiązania wobec mniejszości romskiej. Pierwsze kroki w tej dziedzinie podjął Parlament Europejski, który wydał trzy rezolucje odnoszące się do mniejszości narodowych. Brakowało w nich jednak konkretnego nawiązania bezpośrednio do mniejszości romskich. Przełomowym momentem okazał się 1994 rok, kiedy w rezolucji Parlamentu Europejskiego „O mniejszościach językowych we Wspólnocie Europejskiej" podkreślono znaczenie Romów, a konkretnie wskazano na ich języki, których pielęgnowanie powinno stać się priorytetem Unii Europejskiej i jej państw członkowskich (Sozański, 2010, ss. 138-139). Wraz z procesem rozszerzania się Unii Europejskiej o kolejne państwa w 2004 oraz 2007 roku liczba osób należących do społeczności romskiej we Wspólnocie znacznie się zwiększyła. W związku z tym narastały nowe problemy, które dotykały mniejszość romską w państwach Europy Środkowej i Wschodniej. Romowie, którzy silnie w tamtym czasie odczuli biedę oraz bezrobocie postanowili przenieść się do państw Europy Zachodniej. Przybywanie dużych grup migrantów romskich do państw zachodnioeuropejskich przyczyniło się do wzrostu sprzeczności oraz sporów gtównie o charakterze politycznym. Pojawiające się konflikty i narastające zagrożenia stały się impulsem do głębszej refleksji oraz działań Unii Europejskiej na rzecz mniejszości romskiej (Janiszewski, 2013a, ss. 24-25). Instytucją Unii Europejskiej, któraopierwsza podjęła próbę wprowadzenia nowych rozwiązań politycznych przyczyniających się do poprawy sytuacji Romów, był Parlament Europejski, podejmujący działania w celu zachęcenia innych europejskich organów do wzmożonej aktywności zmierzającej do polepszenia losu społeczności romskiej poprzez wydawanie określonych rezolucji.

W ramach polityki realizowanej przez Unię Europejską w państwach, które zamieszkują osoby należące do mniejszości romskiej prowadzone są starania zmierzające do poprawy ich sytuacji. Bez wątpienia rozszerzenie Unii Europejskiej o nowe państwa przyczyniło się do większej aktywności w tej kwestii z uwagi na częstą dyskryminację oraz społeczne wykluczenie mniejszości romskiej. W wielu państwach członkowskich Unii Europejskiej zdecydowano się na przyjęcie i realizację specjalnych programów, które spowodują większe zainteresowanie mniejszością romską oraz aktywność szczególnie w dziedzinach obejmujących edukację, zwalczanie bezrobocia, dostęp do służby zdrowia czy poprawę warunków socjalnych (Szymańczak, 2012, ss. 2-4).

Istotnym przedsięwzięciem przyczyniającym się do kształtowania polityki Unii Europejskiej wobec Romów były szczyty romskie zaaranżowane z inicjatywy Komisji Europejskiej oraz państw, które sprawowały prezydencję w Unii Europejskiej (Francja i Hiszpania) w 2008 oraz 2010 roku. Głównym motywem zwołania pierwszego szczytu stał się apel Rady Europejskiej z 2007 roku do użycia wszelkich metod na rzecz włączenia społecznego i poprawy sytuacji Romów. Pierwszy szczyt Unii Europejskiej (wrzesień 2008 roku) był spotkaniem wszystkich zainteresowanych środowisk, które wykazały aktywność w tworzeniu i realizacji polityki wobec Romów na szczeblu europejskim, krajowym, regionalnym i lokalnym (Działania Unii Europejskiej przeciwko dyskryminacji, 2009, s. 16). Na szczycie narodził się również pomysł powołania Europejskiej Platformy w sprawie integracji Romów European Roma Platform). Pierwsze spotkanie Platformy odbyło się w 2009 roku w Pradze. Zgromadzenie stanowi forum dialogu pomiędzy przedstawicielami rządów poszczególnych państw członkowskich Unii Europejskiej, innymi organizacjami międzynarodowym, a mniejszością romską. Oba szczyty potwierdziły, iż działania na rzecz włączenia społecznego io zwalczania dyskryminacji to zgodna odpowiedzialność instytucji Unii Europejskiej, rządów państw członkowskich oraz innych organizacji mających kluczowe 
znaczenie dla społeczności romskiej (Komisja Europejska: Dyrekcja Generalna ds. Zatrudnienia, Spraw Społecznych i Równości Szans, 2010, s. 18).

Dla podjęcia skuteczniejszych działań na rzecz mniejszości romskiej uruchomiono specjalne fundusze strukturalne Unii Europejskiej, w szczególności Europejski Fundusz Spoteczny European Social Fund, EFS). W realizacji budżetu Unii Europejskiej na lata 20072013 w ramach Europejskiego Funduszu Społecznego Romowie stanowili znaczną grupę, którym niezbędne jest okazanie wsparcia (Fundation Secretariado Gitano, 2010, s. 9). Komisja Europejska i państwa członkowskie Unii Europejskiej utworzyły EURoma (Europejska sieć na rzecz włączenia społecznego Romów w ramach funduszy strukturalnych), mają na celu popieranie integracji Romów za pośrednictwem Europejskiego Funduszu Społecznego. Ponadto wymienić należy ważną inicjatywę, podjętą w skali europejskiej - „Dekada na rzecz Romów” Decade of Roma). Program powstał z inicjatywy Butgarii, Chorwacji, Czarnogóry, Czech, Macedonii, Rumunii, Serbii, Słowacji oraz Węgier i jest zaplanowany na lata 2005-2015. Głównym celem przedsięwzięcia są działania prowadzące do poprawy sytuacji Romów, obejmujące następujące obszary: edukacja, zdrowie, zatrudnienie oraz warunki mieszkaniowe, ale również zachęcanie do integracji społecznej poprzez eliminowanie barier pomiędzy mniejszością romską a resztą społeczeństwa (Szymańczak, 2012, ss. 3-5).

Unia Europejska wielokrotnie podkreślała konieczność wzmocnionej integracji Romów. Przykład stanowi wydany przez Komisję Europejską „Komunikat w sprawie integracji społecznej i gospodarczej na rzecz Romów w Europie” („Komunikat w sprawie integracji społecznej", b.d.), w którym wezwano państwa członkowskie Unii Europejskiej do wzmożonej współpracy obejmującej zapewnienie Romom możliwości korzystania z istniejących instrumentów finansowych Unii Europejskiej, a zwłaszcza funduszy strukturalnych. Niestety pomimo wszelkich starań wciąż brakuje stanowczych metod i środków umożliwiających rozwiązanie aktualnych problemów, z jakimi boryka się znaczna część ludności romskiej w Unii Europejskiej. W związku z niewystarczającymi staraniami Komisja Europejska 5 kwietnia 2011 roku przedstawiła i przyjęła Komunikat „Unijne ramy dotyczące krajowych strategii integracji Romów do 2020 roku". Zgodnie z koncepcją dokumentu każde państwo członkowskie Unii Europejskiej powinno opracować oraz realizować Krajową Strategię Integracji Romów opierającą się na wysuniętych przez Komisję Europejską propozycjach, które dotyczyć będą czterech głównych filarów: rynku pracy, edukacji, służby zdrowia oraz mieszkalnictwa. Strategia bazuje na następujących priorytetach:

- zagwarantowanie dzieciom romskim dostępu do kształcenia i edukacji - przede wszystkim zapewnienia, aby wszystkie dzieci romskie ukończyły do 2020 r. co najmniej szkołę podstawową,

- zapewnienie Romom pełnego i niedyskryminującego dostępu do rynku pracy, kształcenia zawodowego - zmniejszenie dysproporcji w sferze zatrudnienia między Romami a pozostałym społeczeństwem,

- zapewnienie Romom dostępu do opieki zdrowotnej, szczególnie dla kobiet i dzieci,

- zapewnienie dostępu do zakwaterowania, w szczególności w sferze socjalnej („,Komunikat Unijne ramy dotyczące krajowych strategii integracji Romów", b.d., ss. 5-10).

- Unia Europejska wzywa państwa członkowskie do wypracowania skutecznych metod dla dokonania oceny sprawności wdrażania działań na rzecz Romów. Konieczne jest podjęcie znacznych wysiłków, aby doprowadzić do realizacji oczekiwań określonych w unijnych ramach. 
Efektem wielu przeprowadzonych badań jest stwierdzenie, iż Romowie wciąż zagrożeni są wykluczeniem społecznym, w stopniu znacznie wyższym niż inne mniejszości narodowe i etniczne. Wykluczenie szczególnie widoczne jest w zakresie: rynku pracy oraz edukacji. Mniejszość romska powszechnie postrzegana jest przez pryzmat stereotypów oraz głęboko zakorzenionych uprzedzeń społeczeństwa.

Uczestnictwo mniejszości romskiej w systemie edukacji kształtuje się na niskim poziomie. Powszechnie występuje zjawisko tworzenia tzw. gett szkolnych (szkół tylko dla Romów), niedostateczna liczba odpowiednio wykwalifikowanych pedagogów i nauczycieli oraz brak motywacji ze strony rodziców do wysyłania dzieci do szkół. Rodziny romskie, których często dotyka problem ubóstwa, nie przeznaczają wystarczających środków finansowych na edukację. Dzieci mniejszości romskiej nie mają odpowiednich podręczników, zeszytów, wyprawek i przyborów szkolnych, a także stosownego ubrania. Podejście rodziców stanowi niewątpliwie problem, ponieważ nie wiążą oni postępów w sferze edukacji z jakimkolwiek sukcesem zawodowym (Mazur, 2010, s. 144).

Ważnym powodem, który również zniechęca Romów do kierowania dzieci do szkót, jest strach przed zapoznaniem się dzieci z odmiennymi wzorcami kulturowymi, których przyswajanie jest zupełnie zbędne. Szkoła uznawana jest jako miejsce, w którym dzieci romskie odrywane są od własnej tożsamości. Należy w tym miejscu zaznaczyć także, iż sytuacja romskich kobiet w obszarze edukacji jest o wiele trudniejsza niż mężczyzn. Dziewczynki odpowiedzialne są za wykonywanie obowiązków domowych, co powoduje, że często przerywają naukę. Brak udziału dzieci romskich w systemie edukacji stanowi zagrożenie $w$ przyszłym życiu, ma odbicie $w$ ograniczonym dostępie do rynku pracy czy odrzuceniu społecznym. Społeczność romska musi zdać sobie sprawę, iż wysoki poziom edukacji wpływa pozytywnie na wzrost potencjału młodych Romów (Szewczyk, 2013, ss. 56-59).

Kolejnym problemem mniejszości romskiej, który powoduje ograniczenia w integracji z obywatelami państw członkowskich Unii Europejskiej, jest niski poziom zatrudnienia. Trudności, które napotykają osoby należące do społeczności romskiej na rynku pracy spowodowane są brakiem konkretnego określenia statusu prawnego, niskim poziomem posiadanego wykształcenia, a w konsekwencji niedostatecznymi kwalifikacjami zawodowymi oraz doświadczanymi ze strony przyszłych pracodawców uprzedzeniami i dyskryminacją. Faktem jest, iż podjęcie pracy wymieniane jest jako jeden z ważniejszych składników, które wpływają na proces integracji (Mazur, 2010, s. 145).

Bezrobocie wśród Romów jest kilkakrotnie wyższe niż wśród pozostałych obywateli Unii Europejskiej; nie ulega wątpliwości, że Romowie znajdują się w gorszej sytuacji na rynku pracy. Czynnikami, które szczególnie decydują o występowaniu wśród mniejszości romskiej zjawiska bezrobocia, są edukacja, dyskryminacja oraz kultura. W przypadku edukacji problem Romów polega na dużych brakach w umiejętności pisania i czytania, co w konsekwencji przejawia się posiadaniem niedostatecznych kwalifikacji zawodowych. Bardzo istotną kwestią, która ogranicza społeczności romskiej możliwość podjęcia zatrudnienia, są uwarunkowania kulturowe. Mniejszość romska postępuje według narzuconych z góry nakazów i zakazów zebranych w tzw. kodeks postępowania - Romanipen, który uniemożliwia podjęcie pracy w określonych zawodach. Pomimo wielu działań prowadzonych przez państwa członkowskie Unii Europejskiej zmierzających do znalezienia sposobu na rozwiązanie problemu osób należących do mniejszości romskiej, które są długotrwale bezrobotne, nie udało się osiągnąć zadowalających efektów (Szewczyk, 2013, ss. 50-53). 
Na podstawie analizy problematyki mniejszości narodowych i etnicznych w Unii Europejskiej ze szczególnym uwzględnieniem mniejszości romskiej sformułowano następujące wnioski:

1. Unia Europejska znajduje się dopiero na etapie tworzenia systemu ochrony mniejszości narodowych i etnicznych, a więc jest jeszcze na dalekiej drodze do wyznaczania standardów w tej dziedzinie. Unia Europejska w przyszłości może odgrywać rolę lidera, jednak niezbędne będzie podjęcie wielu starań, debat oraz działań, w które koniecznie zaangażowane muszą być wszystkie państwa członkowskie. Próby podejmowane przez Parlament Europejski w celu poprawy sytuacji mniejszości narodowych i etnicznych w Unii Europejskiej mogą być odpowiednim impulsem do wstępnych refleksji.

2. Efektywna ochrona mniejszości narodowych i etnicznych w Unii Europejskiej nie może opierać się jedynie na zagwarantowaniu przez państwa członkowskie równości osobom należącym do mniejszości we wszystkich dziedzinach życia społecznego, alem musi polegać na wprowadzeniu dodatkowych gwarancji oraz takiej ochronie przedm dyskryminacią, która będzie przynosiła widoczne efekty. Zadowalający poziom ochrony mniejszości narodowych i etnicznych w Unii Europejskiej zostanie osiągnięty, gdy zapewnione zostaną odpowiednie warunki rozwoju tożsamości mniejszości oraz przysługiwały jej będą prawa, z których korzysta większość obywateli.

3. Polityka edukacyjna Unii Europejskiej wobec mniejszości narodowych i etnicznych w ostatnich latach wyraźnie się rozwinęła. Dokonała wielu postępów począwszy od edukacji, która doprowadzić miała do asymilacji, aż do edukacji wielokulturowej mającej na celu przede wszystkim wyeliminowanie poczucia strachu przed "obcymi", w tym przypadku mniejszościami narodowymi i etnicznymi.

4. Integracja społeczna jest najważniejszą płaszczyzną gwarantującą integrację europejską, która stanowi podstawę dla przyszłości funkcjonowania Unii Europejskiej. Społeczność europejska, którą charakteryzować będzie wspólna tożsamość, nie będzie składała się jak do tej pory z poszczególnych państw, lecz z narodów zachowujących własną różnorodność.

5. Pomimo wielu starań Unii Europejskiej oraz wykorzystania funduszy unijnych sytuacja mniejszości romskiej poprawiła się tylko nieznacznie. Głównymi tego przyczynami są niedostateczne działania ze strony Unii Europejskiej, korupcja urzędników, a także brak zainteresowania społecznością romską ze strony państw członkowskich. Dotychczas podjęte działania nie przyniosły zamierzonych rezultatów, dlatego konieczne jest poświęcenie większej uwagi tej kwestii. Unia Europejska potrzebuje mocnego wsparcia innych instytucji unijnych oraz społeczeństwa obywatelskiego. Lepsza współpraca między poszczególnymi podmiotami może zwiększyć skuteczność działań, które wciąż uznawane są za niewystarczające.

6. Zjawisko wykluczenia społecznego mniejszości romskiej często związane jest z trybem życia, zwyczajami oraz wzorcami odmiennymi od reszty społeczeństwa. Pomoc oferowana przez Unię Europejską i państwa członkowskie zazwyczaj postrzegana jest jako próba naruszenia kultury mniejszości romskiej i zastąpiene jej inną. Ze względu na silną więź tożsamości, społeczność romska wszelkie przejawy zmian w kierunku unijnych oczekiwań postrzega negatywnie, dlatego Unia Europejska powinna wypracować szereg mechanizmów i środków prowadzących do zmian, które mogą zostać przez Romów zaakceptowane, a jednocześnie nie zniszczą rodzimej kultury romskiej.

Głównym problemem, który dotyka społeczność romską, jest długa i trudna droga integracji oraz akceptacji ze strony pozostałych obywateli Unii Europejskiej. Powszechnym 
zjawiskiem jest niechęć do obcych, którzy są ofiarami dyskryminacji. Silnie zakorzenione posługiwanie się stereotypami, brak tolerancji dla odmiennej kultury dowodzi, iż nawet najlepiej skonstruowane programy, inicjatywy Unii Europejskiej nie są wystarczające. Przede wszystkim potrzeba zaangażowania oraz nieprzymuszonej edukacji międzykulturowej zarówno ze strony mniejszości romskiej, jak i reszty społeczeństwa, która prowadzić będzie do poszanowania wzajemnej odmienności.

\section{BIBLIOGRAFIA}

Chodubski, A. (2013). Światowe tendencje rozwoju mniejszości narodowych i etnicznych. W A. Chodubski \& L. Ozdarska, Europejskie doświadczenia mniejszości narodowych i etnicznych. Warszawa: Instytut Wydawniczy "Książka i Prasa".

Discrimination in the EU in 2009, Special Eurobarometer 317. (2009). Pobrano 18 grudnia 2013, z http://ec.europa.eu/public_opinion/archives/ebs/ebs_317_en.pdf

Divido, J. F., Brigham, J. C., Johnson, B. T., \& Gaertner, S. L. (1999). Stereotypizacja, uprzedzenia i dyskryminacja: spojrzenie z innej perspektywy. W N. Macrae, C. Strangor, \& M. Hewstone (Red.), Stereotypy i uprzedzenia: najnowsze ujęcie. Gdańsk: Gdańskie Wydawnictwo Psychologiczne.

Dyrektywa Rady 2000/43/WE z dnia 29 czerwca 2000 roku wprowadzająca w życie zasadę równego traktowania osób bez względu na pochodzenie rasowe lub etniczne. (2000). Pobrano 14 grudnia 2013, z http://eur-lex.europa.eu/LexUriServ/LexUriServ. do?uri=CELEX:32000L0043:pl:HTML

Działania Unii Europejskiej przeciwko dyskryminacji: sprawozdanie z działalności w latach 2007-2008. (2009). Luksemburg: Dyrekcja Generalna ds. Zatrudnienia, Spraw Społecznych i Równości Szans.

European Union Agency for Fundamental Rights. (2009). European Union Minorities and Discrimination Survey 2009: The Roma. Pobrano 21 grudnia 2013, z http://fra.europa. eu/sites/default/files/fra_uploads/413-EU-MIDIS_ROMA_EN.pdf

European Union Agency for Fundamental Rights. (2011). Respect for and protection of persons belonging to minorities: 2008-2010. Luxembourg: EUR-OP. Pobrano 14 grudnia 2013, z http://fra.europa.eu/sites/default/files/fra_uploads/1769-FRA-Report-Respect-protection-minorities-2011_EN.pdf

European Union Annual Report on Human Rights 2001. (b.d.). Pobrano 14 grudnia 2013, z www.manskligarattigheter.gov.se/dynamaster/file_archive/020417/edb0b299e6b26ffe6820be23d73ce0e5/eu_arsrapport2001.pdf

Europejska Karta Języków Regionalnych i Mniejszościowych z dnia 5 listopada 1992 roku (Dz. U. 2009, Nr 137, poz. 1121). (2000). W G. Janusz \& P. Bajda, Prawa mniejszości narodowych: standardy europejskie. Warszawa: Wspólnota Polska.

Fundation Secretariado Gitano. (2010). Situation of Roma In the European Union: A general overview. Pobrano z http://www.gitanos.org/upload/75/60/FSG_-_Situation_of_ Roma_in_the_EU.pdf

Gronowska, B. (1991). Rada Europy wobec problemu mniejszości narodowych. Sprawy Międzynarodowe, (10).

Grzymała-Kozłowska, A. (2002). Trzy wymiary tolerancji w Polsce i w Europie. W A. Jasińska-Kania \& M. Maroda (Red.), Polacy wśród Europejczyków: wartość spoteczeństwa 
polskiego na tle innych krajów europejskich (ss. 187-212). Warszawa: Wydawnictwo Naukowe Scholar.

Janiszewski, P. (2013a). Kształtowanie polityki Unii Europejskiej wobec Romów. W E. Subocz \& S. Garbart (Red.), Wspótczesne wyzwania polityki wobec romskiej mniejszości etnicznej-edukacja, dyskryminacja, wykluczenie społeczne (ss. 15-40). Warszawa: Instytut Wydawniczy "Książka i Prasa".

Janiszewski, P. (2013b). Unia Europejska wobec mniejszości narodowych i etnicznych. W A. Chodubski \& L. Ozdarska (Red.), Europejskie doświadczenia mniejszości narodowych i etnicznych (ss. 38-58). Warszawa: Instytut Wydawniczy "Książka i Prasa".

Janusz, G., \& Bajda, P. (2000). Prawa mniejszości narodowych: standardy europejskie. Warszawa: Stowarzyszenie „Wspólnota Polska”.

Karta Praw Podstawowych Unii Europejskiej (Dz. Urz. UE 2012, C 326). (2012). Pobrano 14 grudnia 2013, z http://oide.sejm.gov.pl/oide/?option=com_content\&view=article\&id $=14428 \& \mid$ temid $=422$

Komisja Europejska: Dyrekcja Generalna ds. Zatrudnienia, Spraw Społecznych i Równości Szans. (2010). Promowanie równości: działania przeciwko dyskryminacji w 2009 r. Pobrano 21 grudnia 2013, z http://rownosc.info/customers/rownosc/web/attachments/9d db4877018fa4712942e0e0897b4daf8169cb5a.pdf

Komunikat Unijne ramy dotyczące krajowych strategii integracji Romów do 2020 roku. (b.d.). Pobrano 21 grudnia 2013, z http://europa.eu/rapid/press-release_PRES-11-135_ pl.htm

Komunikat w sprawie integracji społecznej i gospodarczej na rzecz Romów w Europie. (b.d.). Pobrano 21 grudnia 2013, z http://eur-lex.europa.eu/LexUriServ/LexUriServ. do? uri=CELEX:52010DC0133:pl:NOT

Konwencja Ramowa o Ochronie Mniejszości Narodowych z dnia 1 lutego 1995 roku. (2002). Dz. U. 2002, Nr 22, poz. 209.

Konwencja w sprawie Zwalczania Dyskryminacji w Dziedzinie Oświaty z dnia 15 grudnia 1960 roku (Dz. U. 1964, Nr 40, poz. 268). (b.d.). Pobrano 16 grudnia 2013, z http://libr. sejm.gov.pl/tek01/txt/onz/1960.html

Koss-Goryszewska, M. (2010). Polska polityka antydyskryminacyjna wobec mniejszości narodowych, etnicznych i rasowych w świetle prawa Unii Europejskiej. Warszawa: Instytut Spraw Publicznych. Pobrano z http://www.isp.org.pl/uploads/pdf/1740718487.pdf

Kowalewski, T. (2006). Kształtowanie europejskiej przestrzeni edukacyjnej z polskiej perspektywy. W J. Polakowska-Kujawa (Red.), Współczesna Europa w procesie zmian: wybrane problemy. Warszawa: Wydawnictwo Difin.

Krasnowski, A. (2011). Cyganie/Romowie w Polsce i w Europie: wybrane problemy historii i współczesności. Warszawa: Kancelaria Senatu, Biuro Analiz i Dokumentacji. Pobrano z http://www.senat.gov.pl/gfx/senat/pl/senatopracowania/5/plik/ot-603.pdf

Kwadrans, Ł. (2007). Problemy Romów w Unii Europejskiej. W Z. Jasiński \& T. Lewowicki (Red.), Miejsce kultur etnicznych i regionalnych w jednoczącej się Europie. Opole: Wydawnictwo Uniwersytetu Opolskiego.

Łobodziński, S. (2002). Ochrona praw osób należących do mniejszości narodowych i etnicznych - perspektywa europejska. Warszawa: Kancelaria Sejmu Biuro Studiów i Ekspertyz, Wydział Analiz Ekonomicznych i Społecznych, Raport 208.

Łodziński, S. (2006). Ochrona mniejszości narodowych w Europie: zasady ochrony ich praw oraz problemy wdrażania ich w życie. W J. Polakowska-Kujawa (Red.), Wspótczesna Europa w procesie zmian: wybrane problemy. Warszawa: Wydawnictwo Difin. 
Łuczak, A. (b.d.). Współczesne działania państw europejskich wobec mniejszości romskiej. Pobrano 20 grudnia 2013, z http://rokor1.pl/index.php?option=com_content\& view=article\&id=612: wspczesne-dziaania-panstw-europejskich-wobec-mniejszosciromskiej\&catid=91:prawo-i-okolice\&ltemid $=182$

Łukaszuk, L. (1990). Mniejszości narodowe w świetle prawa międzynarodowego. Sprawy Międzynarodowe, (5).

Machocka, A. (2006). Przeciwdziałanie dyskryminacji w Unii Europejskiej. W E. Michalik \& H. Chałupczak (Red.), Mniejszości narodowe i etniczne $w$ procesie transformacji oraz integracji. Lublin: Wydawnictwo Uniwersytetu Marii Curie-Skłodowskiej.

Malicka, A. (2004). Ochrona mniejszości narodowych - standardy międzynarodowe i rozwiązania polskie. Wrocław: Wydawnictwo Uniwersytetu Wrocławskiego.

Mazur, S. (2010). Polityki Unii Europejskiej i jej państw członkowskich wobec Romów. W S. Mazur, Krajowe i wspólnotowe polityki publiczne wobec mniejszości romskiej mapa aktywności społeczno gospodarczej Romów. Kraków: Małopolska Szkoła Administracji Publicznej Uniwersytetu Ekonomicznego w Krakowie. Pobrano z http://www. msap.uek.krakow.pl/doki/publ/polityki_romowie.pdf

Mniejszości narodowe, etniczne i językowe w Unii Europejskiej. (b.d.). Pobrano 20 grudnia 2013, z http://www.minority.org.pl/index.php?option=com_content\&view=section \&layout $=$ blog\&id $=4 \& \mid$ temid $=47 \&$ lang $=\mathrm{pl}$

Pawlak, S. (2001). Ochrona mniejszości narodowych w Europie. Warszawa: Wydawnictwo Naukowe Scholar.

Pawlikowski, G. (2011). System ochrony praw osób należących do mniejszości narodowych i etnicznych w Europie. Polityka i Społeczeństwo, (8).

Problematyka mniejszości w UE na konferencji w Lublinie. (2011). Pobrano 20 grudnia 2013, z http://wiadomosci.gazeta.pl/wiadomosci/1,114873,10289502,Problematyka_ mniejszosci_w_UE_na_konferencji_w_Lublinie.html

PROGRESS programme (2007-2013). (b.d.). Pobrano 18 grudnia 2013, z http://ec.europa. eu/social/main.jsp?catld=327\&langld=en

Przewodnictwo Polski w Radzie Unii Europejskiej: raport końcowy z przygotowania i sprawozdania prezydencji. (2012). Warszawa. Pobrano 20 grudnia 2013, z http://oide.sejm. gov.pl/oide/images/files/prezydencja/Raport_koncowy.pdf

Rusnarczyk, B. (b.d.). Tendencje w polityce edukacyjnej wobec imigrantów w wybranych krajach Unii Europejskiej (na przykładzie Francji, Szwecji oraz Polski). Pobrano 16 grudnia 2013, z http://www.publikacje.edu.pl/pdf/7812.pdf

Socha, J. (2010). Romowie w Unii Europejskiej. Pobrano 21 grudnia 2013, z http://www. psz.pl/Romowie-w-Unii-Europejskiej

Sozański, J. (2010). Prawa człowieka w Unii Europejskiej po Traktacie Lizbońskim. Warszawa: Polskie Wydawnictwo Prawnicze.

Sulimowicz, A. (2011). Mniejszości w Unii Europejskiej. Awazymyz, 3(32). Pobrano 20 grudnia 2013, z http://www.awazymyz.karaimi.org/zeszyty/item/55-mniejszosci-w-unii-europejskiej

Szelewa, D. (2010). Integracja a polityka edukacyjna. Pobrano 23 grudnia 2013, z http:// www.csm.org.pl/pl/publikacje1/category/49-2010

Szewczyk, M. (2007). Romowie i Sinthi w systemie Unii Europejskiej. W P. Borek (Red.), Romowie w Polsce i w Europie - historia, prawo, kultura. Kraków: Wydawnictwo Naukowe Uniwersytetu Pedagogicznego.

Szewczyk, M. (2013). Charakterystyka aktywności Unii Europejskiej w zakresie przeciwdziałania wykluczeniu społecznemu Romów oraz jego romskie uwarunkowania 
(Romanipen). W E. Subocz \& S. Garbart (Red.), Współczesne wyzwania polityki wobec romskiej mniejszości etnicznej-edukacja, dyskryminacja, wykluczenie społeczne (ss. 41-78). Warszawa: Instytut Wydawniczy „Książka i Prasa”.

Szymańczak, J. (2012). Działania Unii Europejskiej na rzecz Romów. Analizy Biura Analiz Sejmowych, (3(70)), 1-6.

Tulipan, M. (2002). Program Monitoringu Akcesji do Unii Europejskiej: ochrona mniejszości. Pobrano 10 grudnia 2013, z http://www.opensocietyfoundations.org/sites/default/ files/euminoritypolishtrans_20021125_0.pdf

Wencel, K. (2009). Przeciwdziałanie dyskryminacji za względu na rasę, narodowość i pochodzenie etniczne w wybranych państwach Unii Europejskiej. Analizy, Raporty, Ekspertyzy, (8(29)). Pobrano 18 grudnia 2013, z http://interwencjaprawna.pl/docs/ARE809-dyskryminacja-UE-przepisy.pdf

Wieści z Ratusza: Konferencja „Mniejszości narodowe, etniczne i językowe w Unii Europejskiej" dobiegła końca. (2011). Pobrano 20 grudnia 2013, z http://www.um.lublin.pl/ um/index.php?t=200\&id=154912

Zygierewicz, A. (2011). Polityka Unii Europejskiej na rzecz przeciwdziałania dyskryminacji. Studia Biura Analiz Sejmowych Kancelarii Sejmu, (2(26)), 87-106. 